\title{
The first blind spirostreptid millipede, found in a cave in Morocco; with notes on the genus Odontostreptus Attems, 1914 (Diplopoda, Spirostreptida, Spirostreptidae)
}

\author{
Henrik ENGHOFF $^{1, *}$ \& Ana Sofia REBOLEIRA ${ }^{2}$ \\ ${ }^{1,2}$ Natural History Museum of Denmark, University of Copenhagen, \\ Universitetsparken 15, DK-2100 København Ø, Denmark. \\ "Corresponding author: henghoff@snm.ku.dk \\ 2Email: sreboleira@snm.ku.dk \\ ${ }^{1}$ urn:lsid:zoobank.org:author:FB09A817-000D-43C3-BCC4-2BC1E5373635 \\ ${ }^{2}$ urn:lsid:zoobank.org:author:ACAEE180-F16C-4488-A4F3-ADC321B049D9
}

\begin{abstract}
The first eyeless species of the suborder Spirostreptidea, Odontostreptus fadriquei sp. nov., is described from a cave in Morocco. The new species, which exhibits some troglomorphic traits, is compared with the highly variable $O$. maroccanus (Attems, 1914) of which new material is presented.
\end{abstract}

Keywords. Taxonomy, troglobiont, caves, North Africa.

Enghoff H. \& Reboleira A.S. 2020. The first blind spirostreptid millipede, found in a cave in Morocco; with notes on the genus Odontostreptus Attems, 1914 (Diplopoda, Spirostreptida, Spirostreptidae). European Journal of Taxonomy 668: 1-11. https://doi.org/10.5852/ejt.2020.668

\section{Introduction}

Millipedes of the family Spirostreptidae have frequently been found in caves, but with one exception, they do not present troglomorphisms (Krabbe 1982: 81). The exception is Orthoporus kiemi Loomis, 1962, described from a cave in the Yucatan Peninsula, Mexico.

The family Spirostreptidae counts around 275 described species of medium-sized to very large millipedes. They are distributed mainly in the Afrotropical (including Madagascar) and Neotropical regions, with a few marginal occurrences in southern North America, North Africa and the Middle East (Enghoff et al. 2015). Two genera of Spirostreptidae occur in the southernmost fringe of the Palaearctic subregion: Archispirostreptus Silvestri, a mainly Afrotropical genus, is represented by A. syriacus (Saussure, 1859) in Israel, Syria, and the Arabian Peninsula, and (stretching the delimitation of the Palaearctic) by A. lugubris (Brölemann, 1901) ssp. villiersi (Schubart, 1951) in the Aïr Mts in Sahara (Mwabvu et al. 2010); in addition, fragments of an unidentified species of Archispirostreptus have been found in Libya (Enghoff \& Van Neer submitted). In the western part of North Africa, in Morocco, spirostreptids of the genus Odontostreptus Attems, 1014, are not uncommon. Odontostreptus currently includes 13 species, most of which occur in Central and Western Africa, but O. maroccanus (Attems, 1914) and O. lepineyi 
(Verhoeff, 1938) are restricted to Morocco (Krabbe 1982), isolated from their congeners by the Sahara desert.

Here, we describe a new Moroccan species of Odontostreptus, collected in a cave and clearly troglomorphic. Very few species of troglobiont millipedes are known from Morocco, including three species of Paradoxosomatidae: Jeekelosoma abadi (Mauriès, 1985), J. heptarachne Enghoff \& Reboleira, 2019, and J. viginti Enghoff \& Reboleira, 2019, one species of Chamaesomatidae: Origmatogona strinatii Manfredi, 1956, and one species of Opisthocheiridae: Ceratosphys maroccana Mauriès, 1985.

\section{Material and methods}

Specimens were obtained from the collection of the Zoological Museum of Barcelona (MZB) and the Natural History Museum of Denmark (NHMD, formerly ZMUC).

Specimens were examined under a binocular stereo microscope Leica M165C, and measurements were made with the software Leica Application Suite ver. 4.12. Habitus were photographed with a Cannon 6D equipped with a macrolens. The gonopods were dissected and mounted on temporary slides in lactic acid or glycerine for study under light microscopy in a Leica DM2500 microscope. For scanning electron microscopy (SEM) specimens were mounted on aluminium stubs, coated for 110 seconds with platinum/ palladium, and studied in a JEOL JSM-6335F microscope. The background of some SEM images was processed with Adobe Photoshop CS6.

\section{Results}

Class Diplopoda de Blainville in Gervais, 1844

Order Spirostreptida Brandt, 1833

Suborder Spirostreptidea Brandt, 1833

Family Spirostreptidae Brandt, 1833

Genus Odontostreptus Attems, 1914

Diagnosis (based on Krabbe 1982)

Differs from other genera of Spirostreptidae by having a gonopod telopodite with an antetorsal process and a terminal, large, ladle-like lamella protecting an unbranched solenomere, in combination with having a simple gonopod coxal metaplica without terminal lamellae, moderately developed prefemoral processes on the first pair of male legs, a dorsally smooth preanal ring, and body rings without longitudinal keels.

Of the 13 included species (Krabbe 1982), two are restricted to Morocco, viz., O. maroccanus (Attems, 1914) and O. lepineyi (Verhoeff, 1938). The latter is very poorly known; it was described from a female and according to Schubart (1960) may be a synonym of $O$. maroccanus tidsiaccola. In contrast, O. maroccanus has been collected frequently. In its present concept it is quite a variable species; the following forms have been described:

- O. maroccanus tidsiaccola (Brolemann, 1928)

- O. maroccanus ahmedensis (Brolemann, 1928)

- a form of ahmedensis with particularly many body rings (Schubart 1960)

- a form of ahmedensis ("Rif-Form") with ozopores on body ring 5 (Schubart 1960)

Schubart $(1952,1960)$ considered the possibility that ahmedensis could be a separate species. We here present some notes and illustrations of $O$. maroccanus s. lat., but a clarification must await a study of a much more comprehensive material. On the other hand, we are confident in describing the new eyeless Odontostreptus as a separate species. 


\section{Odontostreptus fadriquei sp. nov. urn:1sid:zoobank.org:act:767E2E89-4A01-4CA1-B246-09C4792F4333}

Figs 1-2

\section{Diagnosis}

Differs from other species of Odontostreptus, and from all other known spirostreptid millipedes, by the lack of eyes. Further differs from all other known species of Odontostreptus by its smaller diameter.

\section{Etymology}

The species is dedicated to our friend Floren Fadrique, intrepid collector of invertebrates in caves of Morocco.

\section{Material examined}

Holotype

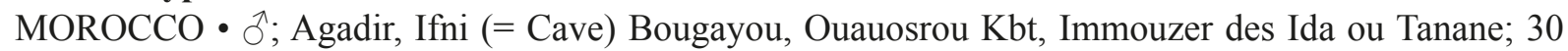
Jul. 2003; A. Ighious, J. Esguius and F. Fadrique leg.; MZB 2003-1301.

\section{Paratype}

MOROCCO • 1 क; same collection data as for holotype; MZB 2019-2016.

\section{Description}

\section{Male}

SizE. Body length $39 \mathrm{~mm}$, vertical midbody diameter $1.34 \mathrm{~mm}$. 70 podous +2 apodous rings in front of telson.

CoLour. Uniform pale yellowish-whitish, faint dark shadows posteriorly on some metazonites.

HEAD. No eyes. Antennae reaching back to end of body ring 6; relative lengths of antennomeres 2-7: $21 / 19 / 20 / 18 / 18 / 4$.

Collum. Lateral lobes broadly rounded, with ca 4 faint striae.

Body RINGS. Very faintly constricted between pro- and metazonite. Prozonites without concentric furrows; metazonites dorsally smooth, laterally (from well above ozopores) and ventrally with regular, fairly dense longitudinal striae. Ozopores starting on body ring 6, situated ca in middle of metazonites.

Legs. Projecting laterad of body rings, tibia visible from above. Relative lengths of podomeres: prefemur 19/femur 19/postfemur 16/tibia 13/tarsus 20/claw 12. Indistinct ventral pads on postfemur, and slightly more distinct one on tibia, on anterior postgonopodal legs. First pair with short, apically rounded, diverging prefemoral lobes.

TELson. Completely smooth; preanal ring without a process; anal valves with raised distal margins, the "labiate" type of Hoffman (2011: fig. 10).

Gonopods (Fig. 2). Sternum (not visible in Fig. 2) triangular, low, not reaching end of paraxocite ( $p x$ ). Coxal proplica $(p p)$ with lateral margin very shallowly concave, apical margin concave, slanting distad towards mesal margin. Metaplica $(m p)$ considerably higher than proplica, apically regularly rounded, with a long, subdistal lateral process (lap). Lateral process distinctly set off from main body of metaplica by rounded incision (in), distal to incision straight, regularly tapering and directed laterad and slightly basad. Telopodite $(t l p)$ first directed basad after exit from coxa, then turning mesad at ca right angles 
and passing posterior side of coxa, torsotope $(t p)$ located at this horizontal section, distal to torsotope making another ca $90^{\circ}$ distad turn and ending in a broad, curved lamella ("ladle") protecting short, slender solenomere $(\mathrm{slm})$.

\section{Female (Fig. 1)}

SizE. Body length $60 \mathrm{~mm}$, vertical midbody diameter $1.93 \mathrm{~mm}$. 84 podous rings, no apodous rings in front of telson.

OTHER NONSEXUAL CHARACTERS. As in male, except for relatively shorter appendages.

\section{A}
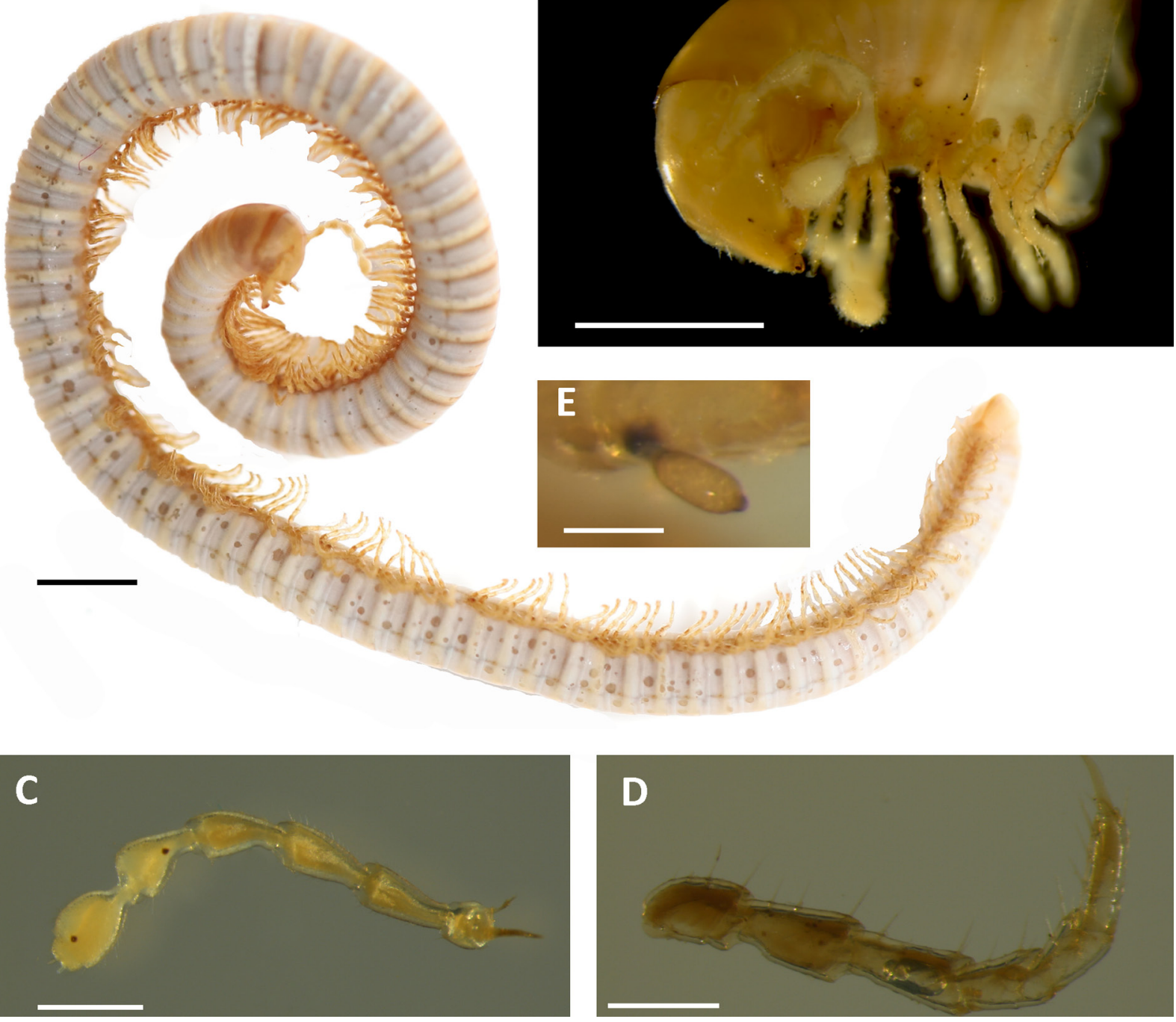

Fig. 1. Odontostreptus fadriquei sp. nov. A, C. + , paratype (MZB 2019-2016). B, D-E. Holotype, ð (MZB 2003-1301). A. Habitus. B. Head and rings 1-6. C. Antenna. D. Midbody leg. E. "Amphoromorph" fungus from leg. Scale bars: $A=2 \mathrm{~mm} ; B=1 \mathrm{~mm} ; C=0.5 \mathrm{~mm} ; D=0.25 \mathrm{~mm} ; E=0.05 \mathrm{~mm}$. 
ENGHOFF H. \& REBOLEIRA A.S., First blind Spirostreptidae millipede
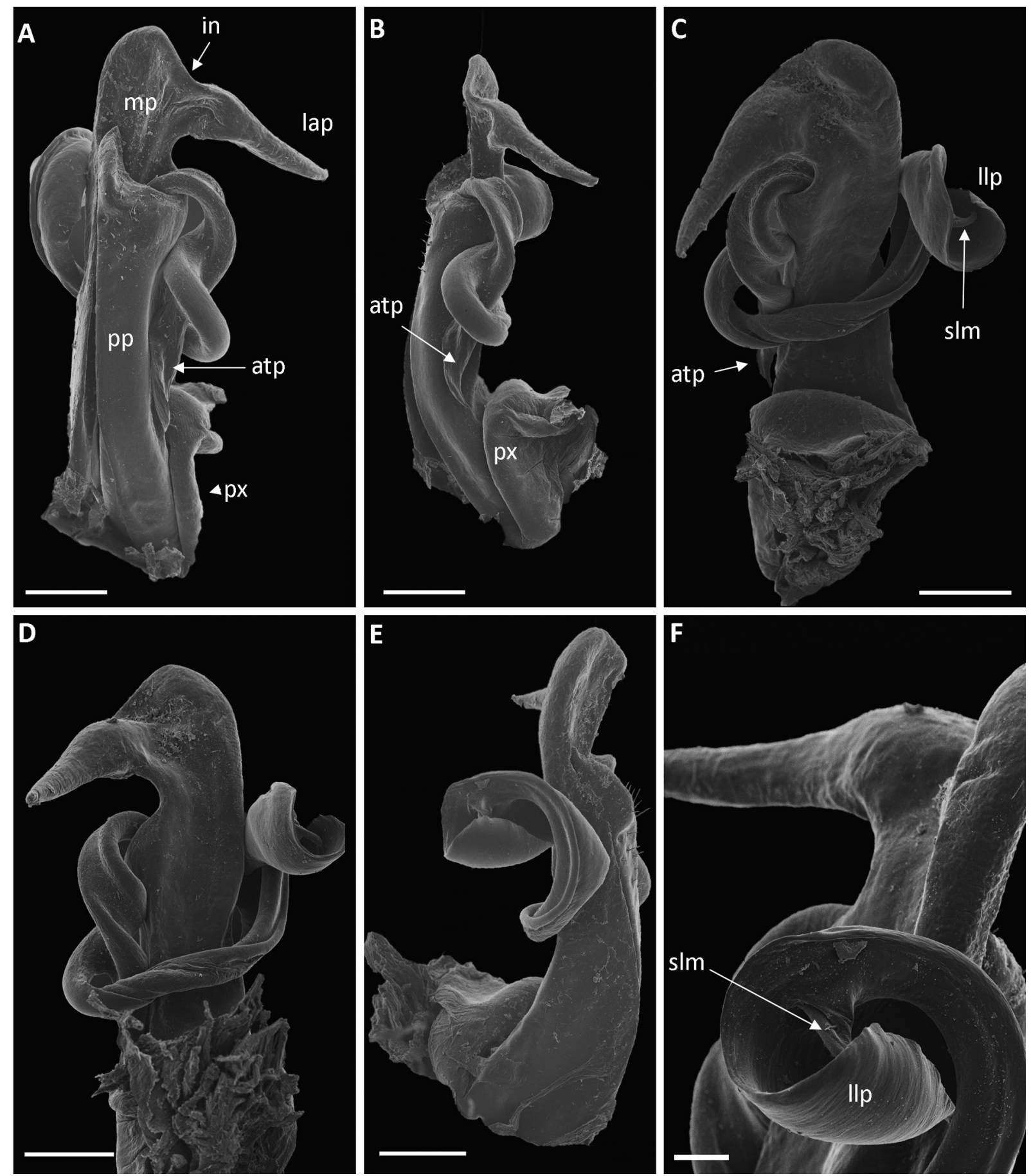

Fig. 2. Odontostreptus fadriquei sp. nov., holotype, đ̊ (MZB 2003-1301), right gonopod. A. Anterior view. B. Lateral view. C. Oblique latero-posterior view. D. Posterior view. E. Mesal view. F. Mesoposterior view. Abbreviations: at $=$ antetorsal process; in $=$ incision; lap $=$ lateral metaplical process; $l l p=$ ladle-like process; $m p=$ metaplica; $p p=$ proplica; $p x=$ paracoxite; $s l m=$ solenomere. Scale bars: $\mathrm{A}-\mathrm{E}=0.2 \mathrm{~mm} ; \mathrm{F}=0.1 \mathrm{~mm}$. 


\section{Remarks}

On the head, antennae and legs of both specimens, thalli of a very conspicuous amphoromorph fungus were seen (Fig. 1E), similar to those reported from other species of millipedes by Enghoff \& Reboleira (2017).

The type locality is a "small cave with sixty meters of horizontal development descending" (F. Fadrique in litt.), located in the Tasroukht plateau, about $60 \mathrm{~km}$ northeast of Agadir. Its biocoenosis includes other cave-adapted species as the staphylinid beetle Domene (Spelaeomene) cantonsi Español, 1972 (Hernando 2007).

Odontostreptus maroccanus (Attems, 1914)

Figs 3-5

Charactopygus maroccanus Attems, 1914: 201, figs 81-82.

Scaphiostreptus maroccanus var. tidsiaccola Brolemann, 1928: 38.

Schaphiostreptus maroccanus var. ahmedensis Brolemann, 1928: 39.

Scaphiostreptus maroccanus - Brolemann 1928: 37. - Krabbe 1982: 163.

Charactopygus maroccanus ahmedensis - Schubart 1952: 206, figs 7-10.

Charactopygus maroccanus tidsiaccola - Schubart 1960: 226.

\section{Material examined}

MOROCCO • 1 đ, 3 우, 2 juv.; Asni area; 1100-1400 m a.s.1.; 8-10 Apr. 1989; Zool. Mus. Copenh.

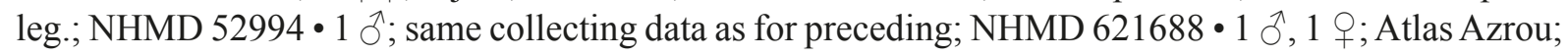
1800 m a.s.1.; 17 Apr. 1985; Cedrus forest; M. Stoltze leg.; NHMD 53003 • 1 juv.; Antiatlas, S Ait-Baha, 70 km NW of Tafraoute; 30.00 N, 0902' W; 12 Mar. 1997; M. Hauser leg.; NHMD $52999 \bullet 1$ क; Ait Oueritane, 2 km from Tinerhir; 14 Apr. 1985; R.M. Kristensen leg.; NHMD 53000 • 1 o; 15-17 km N of Ijoukak along road S501, at river Nfiss; 23 Apr. 1980; J.B. Rasmussen leg.; NHMD 52997・1 ô, 1 ᄋ ; 76 km S of Marrakesh along road P31; 21 Apr. 1980; under stone; J.B. Rasmussen leg.; NHMD 52998 - 1 ડ̊; 10 km before Ouzzane; sifted; 26 Apr. 1980; Mediterranean maquis; G. Osella leg. and ded.; NHMD 53001 • 6 우우 Middle Atlas, Aïn Leuh; 1600 m a.s.1.; 5 Jun. 1975; Sama and Magnani leg.; G. Osella ded.; NHMD 53002.

\section{Descriptive notes}

The studied specimens show a great deal of variation in size, colour, and sculpture. Thus, the specimens in samples NHMD 52999 and 53000 lack prozonital ring furrows (character of ssp. tidsiaccola), and the ones in samples NHMD 53001 and NHMD 53002 have the metazonites clearly vaulted and deeply furrowed even dorsally (character of ssp. ahmedensis). Figure 3 indicates the colour variation (the difference does not seem to be due to preservation), and Figs 4-5 show gonopods of two males, illustrating the variation in, e.g., the distal margin of the proplica ( $p p)$ and the shape of the lateral metaplical process (lap).

\section{Discussion}

Odontostreptus fadriquei sp. nov. shows some troglomorphic characters, notably lack of eyes and pigment. Compared to other spirostreptids, the only other known troglomorphic spirostreptid, Orthoporus kiemi Loomis, 1962, is paler ("nearly white throughout, the only exception being an internal dark spot beneath each pore, doubtless the repugnatorial gland") has smaller eyes, and longer legs (leg span $13 \mathrm{~mm}$, compared with body width $4.5 \mathrm{~mm}$ ) (Loomis 1962). The legs (and antennae) of 
Odontostreptus fadriquei sp. nov., in contrast, are not remarkably long; on the other hand, O. fadriquei sp. nov. completely lacks eyes.

The presence of two apodous rings in front of the telson in the holotype is noteworthy. In Spirostreptidae as a rule, there are no such apodous rings, even in larger juveniles, meaning that the full number of body rings is attained before maturity is achieved, a process known as hemianamorphosis, cf. Enghoff et al. (1993). The holotype of $O$. fadriquei sp. nov., although mature, thus has retained the potential of adding further body rings, but the significance of this cannot be assessed.
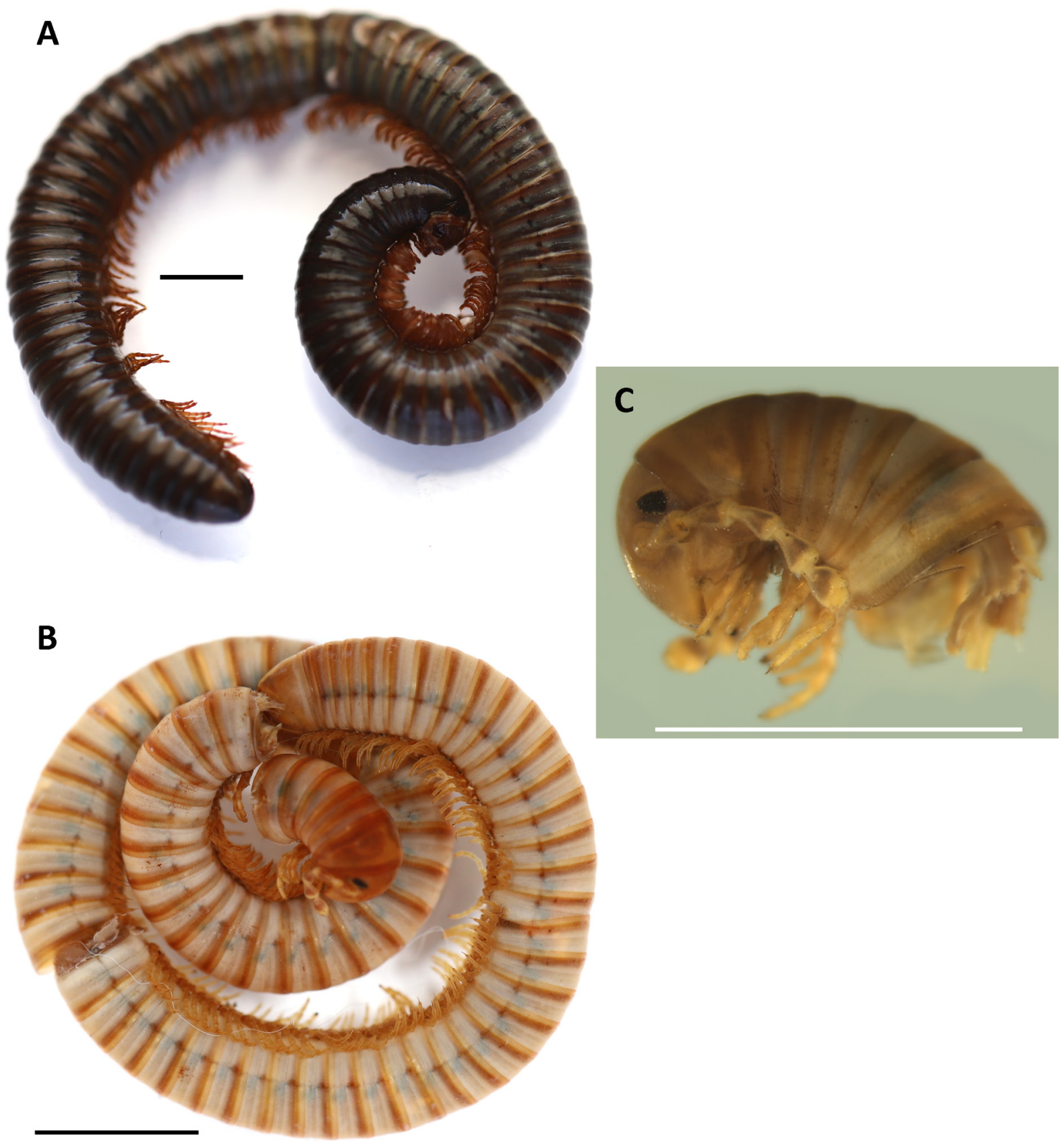

Fig. 3. Odontostreptus maroccanus (Attems, 1914). A. $q$ from the Asni area (NHMD 52994). B-C. 0 , from $10 \mathrm{~km}$ before Ouzzane (NHMD 53001). Scale bars $=5 \mathrm{~mm}$. 

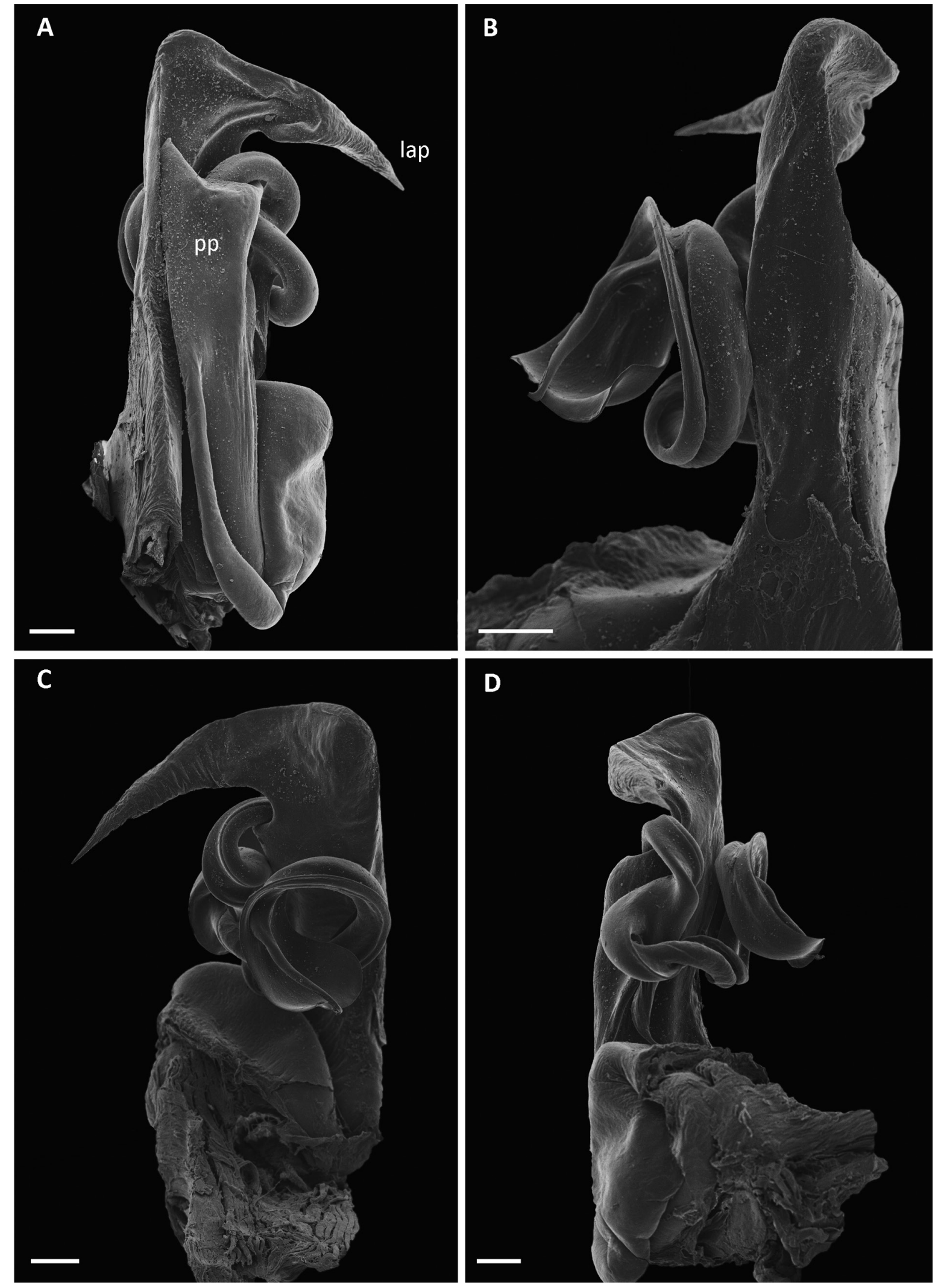

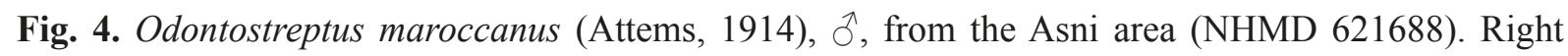
gonopod. A. Anterior view. B. Mesal view. C. Posterior view. D. Lateral view. Abbreviations: lap = lateral metaplical process; $p p=$ proplica. Scale bars $=0.2 \mathrm{~mm}$. 

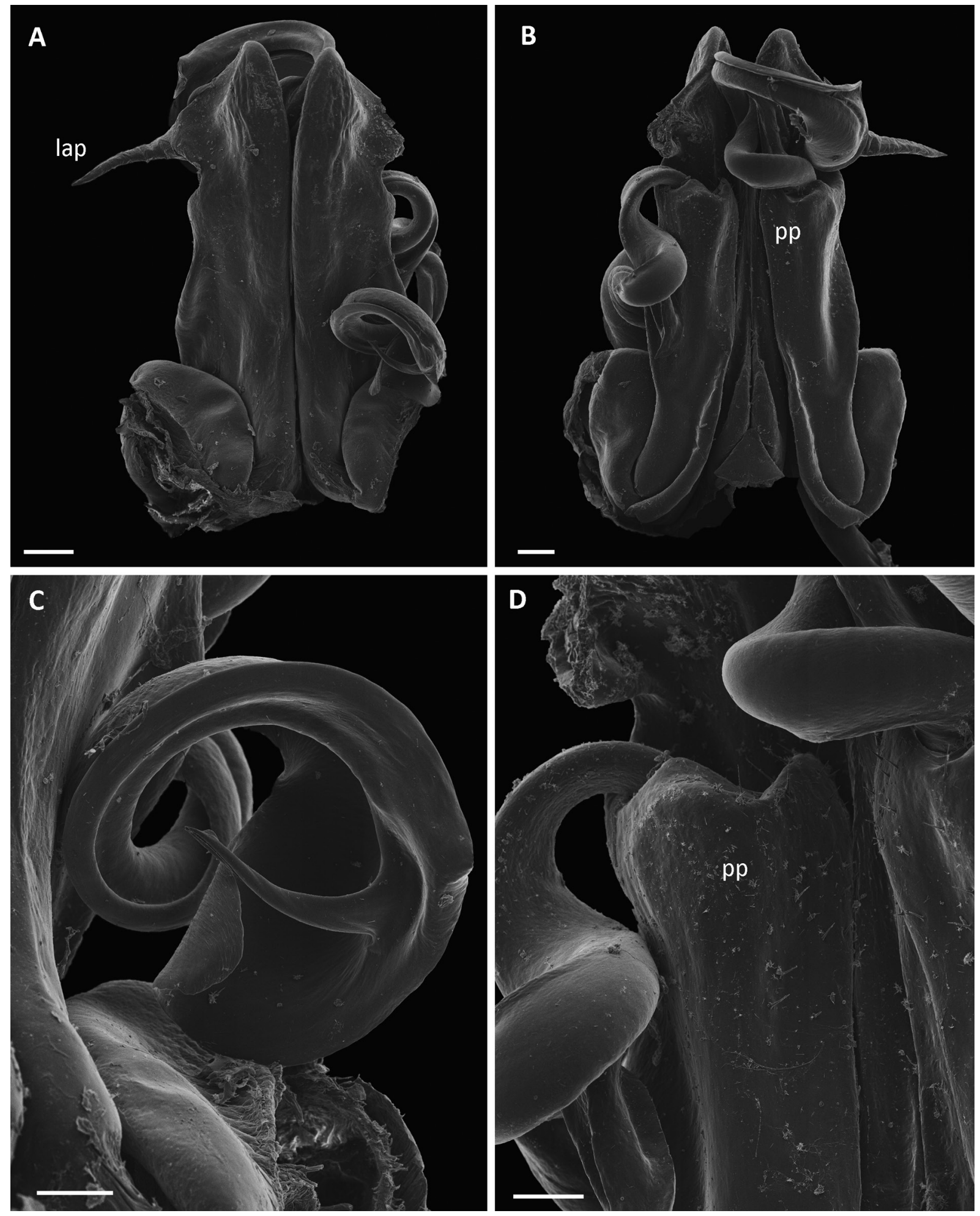

Fig. 5. Odontostreptus maroccanus (Attems, 1914), $\widehat{\partial}$, from $10 \mathrm{~km}$ before Ouzzane (NHMD 53001), gonopods. A. Posterior view. B. Anterior view. C. Tip of left telopodite. D. Detail of left coxa. Abbreviations: lap $=$ lateral metaplical process (broken on left gonopod); $p p=$ proplica. Scale bars: $\mathrm{A}-\mathrm{B}=0.2 \mathrm{~mm} ; \mathrm{C}-\mathrm{D}=0.1 \mathrm{~mm}$. 
In the light of the considerable variation found within $O$. maroccanus s. lat., it might seem premature to describe a new Moroccan species of this genus. Odontostreptus fadriquei sp. nov. does, however, differ significantly from all other Moroccan Odontostreptus. Notably, it is blind and depigmented, and it is much smaller than even the smallest $O$. maroccanus s. lat.: adult male diameter is $1.34 \mathrm{~mm}$ in O. fadriquei, vs 2.1-5.6 $\mathrm{mm}$ in $O$. maroccanus (the lower values were reported from ssp. ahmedensis by Schubart 1960). The variation in the gonopods is apparently uncorrelated with the non-gonopodal characters. Neither Brolemann (1928) nor Schubart (1960) found useful differences between maroccanus s. str., tidsiaccola and ahmedensis in gonopod characters, and the material we have seen supports the conclusion of these authors. The Moroccan Odontostreptus definitely invite a comprehensive analysis which will presumably lead to the recognition of several species, in addition to $O$. maroccanus and O. fadriquei sp. nov.

\section{Acknowledgements}

We express our gratitude to Glòria Masó for giving us access to the Barcelona Museum Diplopoda collection and for loaning the type material, and to our friend Floren Fadrique for kindly providing information and references on cave fauna from the type locality. Hans Reip greatly facilitated our literature search. This research was supported by a research grant (15471) from VILLUM FONDEN.

\section{References}

Attems C. 1914. Afrikanische Spirostreptiden, nebst Überblick über die Spirostreptiden orbis terrarum. Zoologica Stuttgart 25 (65-66): 1-233.

Brolemann H.-W. 1928. Diplopodes des collections de l'Institut scientifique chérifien. Bulletin de la Société des Sciences naturelles du Maroc 8: 34-60.

Enghoff H. \& Reboleira A.S.P.S. 2017. Diversity of non-Laboulbenialean fungi on millipedes. Studies in Fungi 2 (1): 130-137. https://doi.org/10.5943/sif/2/1/15

Enghoff H. \& Van Neer W. submitted. A subfossil spirostreptid millipede from SW Libya (Diplopoda, Spirostreptida, Spirostreptidae). Submitted to Journal of Natural History.

Enghoff H., Dohle W. \& Blower J.G. 1993. Anamorphosis in millipedes (Diplopoda) - the present state of knowledge with some developmental and phylogenetic considerations. Zoological Journal of the Linnean Society 109: 103-234. https://doi.org/10.1111/j.1096-3642.1993.tb00305.x

Enghoff H., Golovatch S., Short M., Stoev P. \& Wesener T. 2015. Diplopoda - Taxonomic overview. In: Minelli A. (ed.) The Myriapoda 2. Treatise on Zoology - Anatomy, Taxonomy, Biology: 363-453. Brill, Leiden and Boston.

Hernando C. 2007. Nuevos datos faunísticos y una nueva especie cavernícola de Domene Fauvel, 1885 subgénero Spelaeomene Español, 1977 de Marruecos (Coleoptera: Staphylinidae: Paederinae). Heteropterus Revista de Entomología 7 (1): 1-6.

Hoffman R.L. 2011. A review of the millipede genus Haplogonopus with commentary on the socalled "Charactopygus-Bildung" modification of spirostreptid paraprocts (Diplopoda: Spirostreptidae). Zootaxa 2734: 53-62. https://doi.org/10.11646/zootaxa.2734.1.4

Krabbe E. 1982. Systematik der Spirostreptidae (Diplopoda, Spirostreptomorpha). Abhandlungen des Naturwissenschaftlichen Vereins in Hamburg (NF) 24: 1-476.

Loomis H.F. 1962. Two unusual Central American spirostreptid millipede species. Proceedings of the Biological Society of Washington 75: 47-52. 
Mwabvu T., Hamer M., Slotow R. \& Barraclough D. 2010. A revision of the taxonomy and distribution of Archispirostreptus Silvestri 1895 (Diplopoda, Spirostreptida, Spirostreptidae), and description of a new spirostreptid genus with three new species. Zootaxa 2567: 1-49.

https://doi.org/10.11646/zootaxa.2567.1.1

Schubart O. 1952. Diplopoden aus Marokko gesammelt vom Institut Scientifique Chérifien. Bulletin de la Société des Sciences naturelles et physiques du Maroc 32: 199-225.

Schubart O. 1960. Ein weiterer Beitrag zur Diplopoden-Fauna Marokkos. Bulletin de la Société des Sciences naturelles et physiques du Maroc 40: 159-232.

Manuscript received: 22 January 2020

Manuscript accepted: 17 March 2020

Published on: 17 June 2020

Topic editor: Rudy Jocqué

Desk editor: Kristiaan Hoedemakers

Printed versions of all papers are also deposited in the libraries of the institutes that are members of the EJT consortium: Muséum national d'histoire naturelle, Paris, France; Meise Botanic Garden, Belgium; Royal Museum for Central Africa, Tervuren, Belgium; Royal Belgian Institute of Natural Sciences, Brussels, Belgium; Natural History Museum of Denmark, Copenhagen, Denmark; Naturalis Biodiversity Center, Leiden, the Netherlands; Museo Nacional de Ciencias Naturales-CSIC, Madrid, Spain; Real Jardín Botánico de Madrid CSIC, Spain; Zoological Research Museum Alexander Koenig, Bonn, Germany; National Museum, Prague, Czech Republic. 